\title{
Rationale of Probiotic Supplementation during Pregnancy and Neonatal Period
}

\author{
Maria Elisabetta Baldassarre ${ }^{1, *} \mathbb{0}$, Valentina Palladino ${ }^{1}$, Anna Amoruso ${ }^{1}$, Serena Pindinelli ${ }^{1}$,

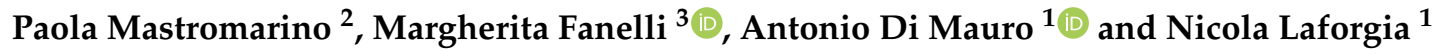 \\ 1 Neonatology and Neonatal Intensive Care Unit, Department of Biomedical Science and Human Oncology, \\ “Aldo Moro" University of Bari, P.zza Giulio Cesare 11, 70124 Bari, Italy; \\ valentinapalladino@hotmail.it (V.P.); amorusoanna@hotmail.it (A.A.); stefsere@alice.it (S.P.); \\ antonio.dimauro@uniba.it (A.D.M.); nicola.laforgia@uniba.it (N.L.) \\ 2 Section of Microbiology, Department of Public Health and Infectious Diseases, Sapienza University, Piazzale \\ Aldo Moro 5, 00185 Rome, Italy; paola.mastromarino@uniroma1.it \\ 3 Department of Interdisciplinary Medicine, “Aldo Moro” University of Bari, 70100 Bari, Italy; \\ margherita.fanelli@uniba.it \\ * Correspondence: mariaelisabetta.baldassarre@uniba.it; Tel.: +39-080-5592220 or +39-3296114818
}

Received: 24 September 2018; Accepted: 3 November 2018; Published: 6 November 2018

\begin{abstract}
Probiotics are living microorganisms that confer a health benefit when administered in adequate amounts. It has been speculated that probiotics supplementation during pregnancy and in the neonatal period might reduce some maternal and neonatal adverse outcomes. In this narrative review, we describe the rationale behind probiotic supplementation and its possible role in preventing preterm delivery, perinatal infections, functional gastrointestinal diseases, and atopic disorders during early life.
\end{abstract}

Keywords: "Probiotics”[Mesh]; “Pregnancy”[Mesh]; “Infant, Newborn”[Mesh]

\section{Introduction}

Gut microbiota is a heterogeneous microbial community that includes $10^{14}$ microorganisms comprising predominantly bacteria, but also viruses, archaeans, and protozoa, and is considered as a super-organ that dynamically interacts with the host in a mutual relationship [1,2]. Gut microbiota plays a significant role in human immunology, nutrition, and pathological processes. Despite inter-individual variability, in adults, $80 \%$ of gut microbiota is composed of three dominant phyla: Bacteroidetes, Firmicutes, and Actinobacteria [3]. The final composition of the intestinal microbiota is influenced by multiple factors such as genetic heritage, type of delivery, mode of feeding, administration of probiotics or antibiotics, stress, and infections [4]. The neonatal microbiota is highly different compared to the adult one, since the first is characterized by rapid changes [5]. At birth, the newborn is exposed to a set of bacteria including staphylococci, enterobacteria, and enterococci that immediately colonize the gastrointestinal tract. In the first days of life, the gut is inhabited mainly by Bifidobacterium, Lactobacillus, Clostridium, and Bacteroides. From one to five months of life, the population of the gastrointestinal tract consists of Bifidobacteriales, Lactobacillales, and Clostridiales. At one year of age, the microbiota is similar to the adult one $[6,7]$

Traditionally, babies have been considered sterile in utero while microbes colonize their gut during delivery and after the birth [8]. Several studies suggest that the placenta and amniotic fluid are involved in this process. In fact, the fetus incorporates an initial microbiome before birth $[9,10]$. Placental microbiome composition has been recently characterized, and includes non-pathogenic strains of Bacteroidetes Firmicutes, Fusobacteria, Proteobacteria, and Tenericutes [11]. During pregnancy, 
the ingestion of bacteria present in the amniotic fluid influences the foetal gut microbiome. Further, maternal microorganisms are present in the meconium and in the cord blood [12,13] in the total absence of chorioamnionitis.

The microbiota colonizes the host before birth and matures definitively during the twelve months following delivery [14]. During this moment, the fetus comes into contact with maternal vaginal bacteria that immediately reach the newborn gastrointestinal tract. The gut of infants born vaginally are colonized prevalently with Bifidobacterium and Streptococcus. In contrast, caesarean delivery is associated with a decrease of Bifidobacteria, while Clostridium and Bacteroides prevail [15-17]. There is some evidence that Bifidobacteria influence the development of very common allergic disorders such as atopic eczema and asthma [18,19]. Additionally, cesarean sections, especially as elective procedures, seem to represent a risk factor for autoimmunity and metabolic disorders [20,21]. Moreover, bifidobacteria are the most represented bacteria in the gastrointestinal tract of healthy infants. Beside the type of delivery, other factors affect microbial colonization in newborns. The abuse of antibiotics during pregnancy or after birth seems to reduce the number of bifidobacteria [22]. Schumann at al. have recently demonstrated a severe decrease of intestinal aerobic and anaerobic bacteria in rats treated with daily intragastric gavage of amoxicillin [23]. The gestational age at the birth is one of main factors that delineates the profile of gut microbiota. In fact, preterm newborns, in comparison to term births, have higher rates of anaerobic bacterial colonization, in particular Enterobacteriaceae [24] and Enterococcaceae $[25,26]$. During a premature delivery, it is not guaranteed that close contact with the vaginal mucosa and a smaller amount of bacteria are ingested. Additionally, in neonatal intensive care units, the wide use of antibiotics contributes to reduced growth indexes of gut bacteria, creating a restricted microbial population [27]. Abnormal vaginal microbiota or active bacterial infection during pregnancy alter the acquisition of neonatal flora promoting preterm delivery [28]. The presence of pathogenic bacteria in the amniotic fluid activates the innate immune response, and the production of prostaglandins increases uterine contractility, promoting premature birth [29].

Moreover, breastfeeding is another important determining factor in establishing the gut microbiome, and is a source of short- and long-term health benefits for the child. In the short term, it has been observed that it decreases the risk of infections, diarrhoea, type- 1 diabetes, and necrotizing enterocolitis; while the long term benefits of breastfeeding include protection from the development of diseases like type-2 diabetes, inflammatory bowel disease, and obesity [30]. Breast milk contains fats, proteins, cytokines, enzymes, antibodies, and nutrients that influence the growth of the child and the development of his/her immune system [31]. Other components are antimicrobial agents like lactoferrin, lysozyme, peroxidase, defensins, IgAs, and oligosaccharides. The rich composition of human milk provides passive immunoprotection against infections and inflammation [32].

Among these components, lactoferrin is an important protein in breast milk, mostly in colostrum, and is involved in the regulation of the immune system and inflammatory response. A recent study suggests that during breastfeeding, lactoferrin is transferred to the intestine of the newborn. The fecal concentration of this protein progressively increases in the first month after birth, promoting the growth and differentiation of the immature intestine. Therefore, lactoferrin seems to promote the proliferation of enterocytes and closure of enteric gap junctions regulating the postnatal intestinal development [33]. Finally, lactoferrin is considered as a growth promoter for bifidobacteria, the predominant beneficial microorganism of human gut [34].

Furthermore, there is accumulating evidence that human milk is not sterile, but contains maternally-delivered bacteria, i.e., mainly lactobacilli and bifidobacteria. The number of bacteria ingested by an infant per $800 \mathrm{~mL}$ of milk consumed daily is estimated at $1 \times 10^{5}-1 \times 10^{7}$ [35].

Microorganisms present in the breast milk are transferred from the mother's intestine to the mammary gland through the lymphatic system by dendritic cells by openings in the tight junctions of the intestinal epithelium [36]. The bacteria contained in the breast milk affect the composition of the gut microbiota in infants, and they could protect against infectious diseases and promote the maturation of the immune system. [37,38]. Additionally, other factors in breast milk including oligosaccharides, s-IgA, 
and lactoferrin influence the proliferation of healthy microbiota [7,39]. Intestinal bacteria stimulate endogenous production of s-IgA [40], activation of T regulatory cells [41,42] and anti-inflammation response $[43,44]$. Therefore, appropriate gut colonization through breastfeeding is involved in the correct development of immune system and in prevention of diseases.

Gastrointestinal flora composition differs mostly in breast- and formula-fed infants. Several studies conducted on stool samples of newborns have shown that bifidobacteria are present in the flora of both groups, but their number is higher in breastfed infants in comparison to formula-fed infants; instead, the number of E. coli and Bacteroides is higher in formula-fed infants [6]. These differences remain, even after breastfeeding is discontinued [7].

Current evidence supports a link between the activity and composition of the gut microbiota and human health and disease. The correct development of gut microbiota composition affects many organs, including neural, immune, and gastrointestinal systems. The gut microbiota composition is altered in many diseases, like disorders of the gut-brain axis [45], immune and gastrointestinal disorders [46,47], and allergic diseases [48]. The potential modulation of the gut microbiota through the administration of probiotics is very prominent in the prevention of human diseases starting from pregnancy.

\section{Methods}

An exhaustive search for eligible studies was performed in PubMed, Embase, Medline, Cochrane library and Web of Science database.

The following subject MeSH headings were used: "Probiotics"[Mesh], "Pregnancy"[Mesh], "Lactation"[Mesh], "Breast Feeding"[Mesh], "Premature Birth"[Mesh], "Infection"[Mesh], "Gastrointestinal Diseases"[Mesh]. Furthermore, free text for "allergy", "atopy", "gut-brain axis", and proper Boolean operators "AND" "OR" were also included to be as comprehensive as possible. Additional studies were sought using references in articles retrieved from searches.

Search limits were set for RCT, involving only human subjects, and published between October 2008 and October 2018. The review was limited to studies written in English.

\section{Role of Probiotics Administration in the Prevention of Infection and Preterm Delivery during Pregnancy}

Vaginal microbiota alterations and infections during pregnancy lead to a greater possibility of preterm delivery; this is related to the development of neonatal infections, sepsis, and necrotising entercocolitis. The use of probiotics seems to modulate the composition of vaginal microflora. Vitali et al. have conducted a pilot, non-randomized, controlled, and perspective study that demonstrated the influence on the vaginal microbiota of pregnant women of dietary supplementation with a probiotic mixture containing L. paracasei DSM 24733, L. plantarum DSM 24730, L. acidophilus DSM 24735, and L. delbrueckii subsp. bulgaricus DSM 24734), three strains of bifidobacteria (B. longum DSM 24736, B. breve DSM 24732, and B. infantis DSM 24737), and one strain of Streptococcus thermophilus DSM 24731, produced at Danisco-Dupont, WI, USA and currently sold in Continental Europe and USA under the brand Vivomixx ${ }^{\circledR}$ and Visbiome ${ }^{\circledR}$, respectively. The characterization of vaginal bacteria in women supplemented with this multistrain probiotic showed an increase of bifidobacteria and a reduction of Atopobium vaginae, resulting in the prevention of bacterial vaginosis. Furthermore, IL-4 and IL-10 levels are influenced by alteration in the vaginal microbial environment. The decline of cytokines involved in the antiphlogistic process were noticed in a control women group that did not consume the probiotic mixture [49]. In contrast, Gille et al. in a recent trial demonstrated that the supplementation with Lactobacillus rhamnosus GR-1 and L reuteri RC-14 for two months during pregnancy does not improve the normal composition of vaginal microbiota compared to the placebo group [50].

Group B Streptococcal (GBS) vaginal colonization is considered a principal cause of neonatal sepsis, pneumonia, and meningitis [51]. The Centres for Disease Control and Prevention (CDC) suggest 
parenteral antibiotic administration during delivery as preventive therapy for women diagnosed with GBS at 35 and 37 weeks of gestation [52]. The possible impact of probiotic administration on prevention of infections during pregnancy has been investigated.

Recently, Olsen at al. performed a randomized pilot study to determine a potential causal relationship between probiotic administration during pregnancy and vaginal Group B Streptococcal (GBS) colonization. There was no significant difference in the incidence of GBS vaginal infections between the women supplemented with probiotics and the control group. However, a greater proportion of commensal bacteria was found in pregnant women who had used probiotics [53]. Besides Ho M. et al. conducted a randomized controlled trial to examine the effect of the oral administration of Lactobacillus reuteri RC-14 and Lactobacillus rhamnosus GR-1 in pregnant women with a vaginal and rectal GBS colonization. Compared to the placebo group, women treated with probiotics had significantly-reduced rectal and vaginal GBS colonization rates [54].

Bacterial vaginosis increases the risk of spontaneous preterm delivery and neonatal complications [55]. Few studies have tested the efficacy of probiotics in the prevention of preterm births. A prospective cohort study recently showed that the administration of a milk supplemented with probiotics during pregnancy reduced preeclampsia and preterm delivery risk [56]. Furthermore, a randomised controlled trial tested the early administration effect of Lactobacillus rhamnosus GR-1 and Lactobacillus reuteri RC-14 in women during gestation affected by low/intermadiate grade of vaginosis, to have a reduce premature delivery risk [57].

In a randomized clinical trial, the use of a yoghurt that contained Lactobacillus bulgaris, Streptococcus thermophilus, Probiotic lactobacillus, and Bifidobacterium lactis has been investigated in pregnant women in the treatment of bacterial vaginosis versus the use of clindamycin. Compared to the use of clindamycin, the administration of probiotics has a significant effect only on the reduction of vaginal $\mathrm{pH}$, which seems to be associated with a lower risk of preterm delivery [58]. Therefore, there is no determinant evidence from clinical trials that confirms role of probiotics in the prevention of preterm delivery (Table 1). A recent metanalysis including 21 studies confirms that there is no evidence that the administration of probiotics in pregnant women reduces the risk of preterm delivery [59].

The potential role of probiotics in the prevention of infections during pregnancy and in preterm infants remains unclear, and requires further research. 
Table 1. Role of probiotics administration in the prevention of infection and preterm delivery during pregnancy.

\begin{tabular}{|c|c|c|c|c|c|c|c|}
\hline Author, Year & Study Design & Study Population & $\begin{array}{c}\text { Intervention } \\
\text { Strain } \\
\text { Dose (D) } \\
\text { Start of Treatment (S) } \\
\text { End of Treatment (E) }\end{array}$ & Placebo & Outcomes Evaluations & Follow-Up & Side Effects \\
\hline $\begin{array}{c}\text { Gille et al., } 2016 \\
\text { [50] }\end{array}$ & $\begin{array}{l}\text { Randomized, } \\
\text { placebo-controlled, } \\
\text { triple-blind, parallel group } \\
\text { trial }\end{array}$ & 320 pregnant women & $\begin{array}{l}\text { L. rhamnousus, GR- } 1^{\circledast} \text { and L. reuteri, } \\
\text { RC- }-14^{\circledR} \\
\text { D: } 1 \times 10^{9} \text { colony-forming unit (CFU) } \\
\text { of each strain } \\
\text { S: first trimester of pregnancy } \\
\text { E: after } 8 \text { weeks of treatment }\end{array}$ & $\begin{array}{l}\text { Indistinguishable } \\
\text { placebo capsule }\end{array}$ & $\begin{array}{l}\text { - Proportion of normal vaginal microbiota } \\
\text { Main outcome: probiotics not improve the } \\
\text { normal composition of vaginal microbiota } \\
\text { compared to the placebo group }\end{array}$ & No available & Not observed \\
\hline $\begin{array}{c}\text { Olsen et al., } 2010 \\
\text { [53] }\end{array}$ & $\begin{array}{l}\text { Pilot randomised controlled } \\
\text { trial }\end{array}$ & $\begin{array}{c}34 \text { Group B } \\
\text { streptococcus-positive } \\
\text { pregnant women }\end{array}$ & $\begin{array}{l}\text { Lactobacillus rhamnosus GR-1 (GR-1) } \\
\text { and Lactobacillus fermentum/reuteri } \\
\text { RC-14 (RC-14) } \\
\text { D: } 1 \times 10^{8} \text { CFU viable strain } \\
\text { S: } 36 \text { weeks of gestation } \\
\text { E: for three weeks or until the birth }\end{array}$ & $\begin{array}{l}\text { No probiotics in } \\
\text { control group }\end{array}$ & $\begin{array}{l}\text { - Incidence of vaginal Group B } \\
\text { streptococcus colonization } \\
\text { Main outcome: no significant difference in } \\
\text { the incidence of GBS vaginal infections } \\
\text { between the women supplemented with } \\
\text { probiotics and the control group }\end{array}$ & $\begin{array}{l}6 \text { months after } \\
\text { delivery }\end{array}$ & Not observed \\
\hline Ho et al., 2016 [54] & $\begin{array}{l}\text { Prospective, double-blind } \\
\text { randomized clinical } \\
\text { trial }\end{array}$ & $\begin{array}{l}110 \text { GBS-positive } \\
\text { pregnant women }\end{array}$ & $\begin{array}{l}\text { L. rhamnosus GR- } 1 \text { and L. reuteri } \\
\text { RC- } 14 \\
\text { D: } 1 \times 10^{9} \text { CFU of both strain } \\
\text { S: at } 35 \text { e } 37 \text { weeks of gestation } \\
\text { E: at delivery }\end{array}$ & $\begin{array}{l}\text { Indistinguishable } \\
\text { placebo capsule }\end{array}$ & $\begin{array}{l}\text { - Incidence of vaginal GBS colonization } \\
\text { - Cause of admittance to the neonatal } \\
\text { Unit } \\
\text { Main outcome: Probiotics administration } \\
\text { significantly reduced rectal and vaginal } \\
\text { GBS colonization rate }\end{array}$ & No available & Not observed \\
\hline $\begin{array}{c}\text { Krauss-Silva } \\
\text { Krauss-Silva et al., } \\
2011 \text { [57] }\end{array}$ & $\begin{array}{l}\text { Prospective } \\
\text { Double blind } \\
\text { Randomized } \\
\text { Controlled }\end{array}$ & 664 pregnant women & $\begin{array}{l}\text { Lactobacillus rhamnosus GR-1 and } \\
\text { Lactobacillus reuteri RC-14 } \\
\text { D: } 2 \times 10^{6} \mathrm{CFU} \text { of each strain } \\
\text { S: } 20 \text { weeks of gestation } \\
\text { E: at delivery }\end{array}$ & $\begin{array}{c}\text { Indistinguishable } \\
\text { placebo capsule }\end{array}$ & $\begin{array}{l}\text { - Incidence of spontaneous preterm } \\
\text { delivery } \\
\text { - Neonatal morbidities } \\
\text { Main outcome: no conclusive results on } \\
\text { the efficacy of probiotics in the prevention } \\
\text { of preterm birth }\end{array}$ & No available & $\begin{array}{l}\text { adverse events } \\
\text { minor and } \\
\text { non-specific of } \\
\text { probiotics use }\end{array}$ \\
\hline $\begin{array}{l}\text { Hantoushzadeh et } \\
\text { al., } 2012 \text { [58] }\end{array}$ & $\begin{array}{c}\text { Double-blind, } \\
\text { placebo-controlled, } \\
\text { parallel-group randomized } \\
\text { clinical trial }\end{array}$ & $\begin{array}{l}310 \text { pregnant women } \\
\text { with symptomatic BV }\end{array}$ & $\begin{array}{l}\text { Probiotic yogurt: lactobacillus bulgaris, } \\
\text { streptococcus thermophilus, probiotic } \\
\text { lactobacillus, and bifidobacterium lactis } \\
\text { D: } 100 \mathrm{~g} \text { twice a day for one week } \\
\text { S: third trimester of pregnancy } \\
\text { E: for one week }\end{array}$ & $\begin{array}{l}\text { Orally-administered } \\
\text { clindamycin ( } 300 \\
\text { mg twice a day for } \\
1 \text { week) }\end{array}$ & $\begin{array}{l}\text { - BV cure rate after one week of treatment } \\
\text { - Preterm birth, Premature rupture of } \\
\text { membranes, } \mathrm{pH} \text { decrease and recurrence } \\
\text { Main outcome: reduction of vaginal } \mathrm{pH} \text { in } \\
\text { women supplemented with probiotics }\end{array}$ & Until delivery & Not observed \\
\hline
\end{tabular}




\section{Role of Probiotics Administration in the Prevention of Allergic Diseases}

At birth, the lymphoid system of the newborn is not yet mature and Th1 response is inhibited. Therefore, it is necessary that the immune system clear the gap between Th1 and Th2 response. Microbiota has a crucial role during this critical phase [60]. There is a relationship between gut microbiome patterns and the potential role of modulation of innate immune signaling in the prevention of allergic diseases. West et al. have shown that after the birth, the maturation of the intestinal microbiota influences the innate immune response and the development of atopic eczema. This study suggests that alteration of gut microbial population increases the risk of the development of atopic-eczema due to a lack of modulation on inflammatory cytokines mediated by the microbiome [61]. Moreover, antibiotics, caesarean section, and infant formula are factors that modify microbiome composition and are related to the development of allergic diseases [62].

Probiotic supplementation to mothers during breastfeeding positively influences the microbial composition of breast milk and positively modulates the neonatal immune system mainly through the regulation of both Th1- and Th2-type response and by the stimulation of tolerance [63]. It has been observed that administration to mothers of a probiotic mixture containing L. paracasei DSM 24733, L. plantarum DSM 24730, L. acidophilus DSM 24735, and L. delbrueckii subsp. bulgaricus DSM 24734), three strains of bifidobacteria (B. longum DSM 24736, B. breve DSM 24732, and B. infantis DSM 24737), and one strain of Streptococcus thermophilus DSM 24731 (Danisco-Dupont, WI, USA and currently sold in Continental Europe and USA under the brand Vivomix ${ }^{\circledR}$ and Visbiome ${ }^{\circledR}$, respectively) resulted in an increase of lactobacilli and bifidobacteria in both colostrum and mature milk [7]. This probiotic mixture seems to play a key role in the regulation of the immune response which is influenced by the type of delivery; by comparing women with vaginal delivery under probiotics or placebo, an increase in bifidobacteria and lactobacilli was observed in the colostra and mature milk in the first group; no difference, however, was observed between the two groups of women who underwent caesarean section [63]. Maternal probiotic supplementation before and after delivery seems to prevent atopic eczema in children (Table 2), but further studies are requested to confirm this relation with other allergic disorders.

In a randomized, double-blind trial, women were given probiotic milk or placebo from the 36th week of gestational age to $3 \mathrm{rd}$ month after delivery during breastfeeding. At 2 years of age, all infants were tested for atopic dermatitis, asthma, and other allergic diseases. The study demonstrates that administration of probiotics to mothers during pregnancy decreases the incidence of atopic dermatitis, but has no effect on asthma [64]. Enomoto et al., in an open trial, confirmed that the administration of a combination of Bifidobacteria from 1 month before delivery to mothers and 6 months after birth to babies significantly reduced the incidence of cutaneous allergic diseases (eczema/atopic dermatitis). Moreover, women in the study group exhibit lower fecal Proteobacteria concentrations; this is related to higher children fecal concentration of Bacterioidetes at 4 months of age [65].

In contast, a recent randomized placebo-controlled trial demonstrated that the administration of Lactobacillus rhamnosus HN001 to pregnant woman before and after delivery during breastfeeding seems not to prevent the development of infant eczema, wheeze, and atopic sensitization during the first year of life [66]. In addition, another clinical trial shows that the supplementation of Lactobacillus GG in women from the 6th month of pregnancy and after birth (to mothers during breastfeeding or to infants for 6 months) does not reduce the incidence of developing allergic diseases in children followed up to 36 months of age [67].

Rautava et al. found that maternal supplementation of a mixture of probiotics 2 months before delivery and 2 months after lactation reduces the risk of developing eczema in infants in the first 2 years of life [68]. Furthermore, Kim et al. prove that the maternal supplementation of Bifidobacterium bifidum, B. lactis, and Lactobacillus acidophilus 4-8 weeks before delivery and until 6 months after the birth reduces the prevalence of eczema in the first year of life in children [69]. 
In a pAnda study, a mixture of probiotics (Bifidobacterium bifidum, Bifidobacterium lactis, and Lactococcus lactis) administrated to mothers before delivery and to infants for the first year of life reduced the incidence of eczema during the first 3 months of life compared to placebo group [70].

Simpson et al. have confirmed the long-term protective effect on the baby of probiotic maternal administration: children assessed at 6 years of age have a lower incidence of the development of atopic dermatitis, while this has not been confirmed for other allergic diseases [71]. Therefore, several studies have confirmed the role of probiotics in the early prevention of eczema in children, and these benefits were shown to persist over time. A recent randomized, controlled study (Probiotics in the Prevention of Allergy among Children in Trondheim, ProPACT) in part explains how perinatal maternal probiotics supplementation can play a protective role in the development of atopic dermatitis. In this study T-regs, Th-1, Th-2, and Th-17 lymphocyte or the Th-1/Th-2 ratio seem not to be influenced by a mixture of LGG, La-5, and Bb-12, but this reduces the proportion of Th-22 number [72].

The World Allergy Organization (WAO) convened a guideline panel to develop evidence-based recommendations about the use of probiotics in the prevention of allergies. The WAO guideline panel suggests:

- that by using probiotics in pregnant women at high risk for allergy in their children, there is a net benefit resulting primarily from prevention of eczema (conditional recommendation, very low-quality evidence).

- that by using probiotics in women who breastfeed infants at high risk of developing allergy, there is a net benefit resulting primarily from prevention of eczema (conditional recommendation, very low-quality evidence).

- $\quad$ using probiotics in infants at high risk of developing allergies, because there is a net benefit resulting primarily from prevention of eczema (conditional recommendation, very low-quality evidence).

Currently-available evidence does not indicate that probiotic supplementation reduces the risk of developing allergies in children, but there is a net benefit primarily in the prevention of eczema [73]. 
Table 2. Probiotics administration during pregnancy and after delivery in prevention of allergic disorders.

\begin{tabular}{|c|c|c|c|c|c|c|c|}
\hline Author, Year & Study Design & Study Population & $\begin{array}{l}\text { Intervention } \\
\text { Strain } \\
\text { Dose (D) } \\
\text { Start of Treatment (S) } \\
\text { End of Treatment (E) }\end{array}$ & Placebo & Outcomes Evaluations & Follow-Up & Side Effects \\
\hline $\begin{array}{l}\text { Dotterud et al., } \\
2015 \text { [64] }\end{array}$ & $\begin{array}{c}\text { Randomized, } \\
\text { double-blind trial }\end{array}$ & $\begin{array}{l}415 \text { pregnant } \\
\text { women }\end{array}$ & $\begin{array}{l}\text { Probiotic milk: Biola }{ }^{\circledR} \text { (Tine BA, Oslo, Norway), } \\
\text { contained Lactobacillus rhamnosus GG (LGG), } \\
\text { Bifidobacterium animalis subsp. lactis Bb-12 (Bb-12) and } L \text {. } \\
\text { acidophilus La-5 (La-5). } \\
\text { D: } 5 \times 10^{10} \mathrm{CFU} \text { of LGG and Bb-12, and } 5 \times 10^{9} \\
\text { colony-forming unit (CFU) of La-5 daily } \\
\text { S: } 4 \text { weeks before the expected delivery date (to } \\
\text { mothers) } \\
\text { E: } 3 \text { weeks after delivery(to mothers during } \\
\text { breastfeeding) }\end{array}$ & $\begin{array}{l}\text { Indistinguishable } \\
\text { placebo milk }\end{array}$ & $\begin{array}{l}\text { - Development of atopic diseases in } \\
\text { children (asthma, atopic dermatitis and } \\
\text { allergic rhinoconjunctivitis) } \\
\text { Main outcome: probiotics administration } \\
\text { reduces the incidence of AD in children }\end{array}$ & $\begin{array}{l}24 \text { months after } \\
\text { delivery }\end{array}$ & Not observed \\
\hline $\begin{array}{l}\text { Enomoto et al., } \\
\quad 2014 \text { [65] }\end{array}$ & Open-trial study & $\begin{array}{l}166 \text { pregnant } \\
\text { women }\end{array}$ & $\begin{array}{l}\text { B. longum BB536 [ATCC BAA-999] and B. breve M-16V } \\
\text { [LMG 23729] } \\
\text { D: two sachets, each containing approximately } 5 \times 10^{9} \\
\text { CFU of both probiotics } \\
\text { S: } 4 \text { weeks before the expected delivery date (to } \\
\text { mothers) } \\
\text { E: } 6 \text { months after delivery(to infants) }\end{array}$ & $\begin{array}{l}\text { The control group } \\
\text { no received } \\
\text { probiotics }\end{array}$ & $\begin{array}{l}\text { - Development of allergic symptoms in } \\
\text { children } \\
\text { - Composition of faecal samples (mothers } \\
\text { and infants) } \\
\text { Main outcome: probiotics administration } \\
\text { reduces the incidence of AD/eczema in } \\
\text { children }\end{array}$ & $\begin{array}{l}36 \text { months after } \\
\text { delivery }\end{array}$ & Not observed \\
\hline $\begin{array}{l}\text { Wickens et al., } \\
2018 \text { [66] }\end{array}$ & $\begin{array}{c}\text { Randomized } \\
\text { placebo-controlled trial }\end{array}$ & $\begin{array}{l}423 \text { pregnant } \\
\text { women }\end{array}$ & $\begin{array}{l}\text { Lactobacillus rhamnosus HN001 (HN001) } \\
\text { D: } 6 \times 10^{9} \mathrm{CFU} \\
\text { S: from } 14-16 \text { weeks gestation (to mothers) } \\
\text { E: } 6 \text { months post-partum (to mothers during } \\
\text { breast-feeding) }\end{array}$ & $\begin{array}{l}\text { Indistinguishable } \\
\text { placebo capsules }\end{array}$ & $\begin{array}{l}\text { - Development of atopic diseases in } \\
\text { children } \\
\text { - Immunomodulatory factors in breast } \\
\text { milk (TGF- } \beta 1 \text {, TGF- } \beta 2 \text { ) } \\
\text { Main outcome: probiotic } \\
\text { supplementation not prevent infant } \\
\text { eczema }\end{array}$ & $\begin{array}{l}12 \text { months after } \\
\text { delivery }\end{array}$ & Not observed \\
\hline Ou et al., 2012 [67] & $\begin{array}{c}\text { Prospective, } \\
\text { double-blind, } \\
\text { placebo-controlled } \\
\text { clinical trial }\end{array}$ & $\begin{array}{l}191 \text { pregnant } \\
\text { women }\end{array}$ & $\begin{array}{l}\text { Lactobacillus GG; ATCC 53103; } \\
\text { D: } 1 \times 10^{10} \mathrm{CFU} \text { daily } \\
\text { S: From the second trimester of pregnancy (to mothers) } \\
\text { E: } 6 \text { months post-partum (to mothers during } \\
\text { breastfeeding and to infants) }\end{array}$ & $\begin{array}{l}\text { microcrystalline } \\
\text { cellulose }\end{array}$ & $\begin{array}{l}\text { - Development of allergic diseases in } \\
\text { children. } \\
\text { - Improvement of maternal allergic } \\
\text { symptom score and plasma immune } \\
\text { parameters } \\
\text { Main outcome: probiotic } \\
\text { supplementation not prevent infant } \\
\text { allergic disease }\end{array}$ & $\begin{array}{l}36 \text { months after } \\
\text { delivery }\end{array}$ & Not observed \\
\hline $\begin{array}{l}\text { Rautava et al., } \\
2012 \text { [68] }\end{array}$ & $\begin{array}{l}\text { Parallel, double-blind } \\
\text { placebo-controlled trial }\end{array}$ & $\begin{array}{l}241 \text { pregnant } \\
\text { women }\end{array}$ & $\begin{array}{l}\text { (1) Lactobacillus rhamnosus LPR and Bifidobacterium } \\
\text { longum BL999 (LPR+BL999) } \\
\text { (2) L paracasei ST11 and B longum BL999 (ST11+BL999) } \\
\text { D: } 1 \times 10^{9} \text { CFU for each probiotic } \\
\text { S: } 2 \text { months before delivery (to mothers) } \\
\text { E } 2 \text { months post-partum (to mother during } \\
\text { breast-feeding) }\end{array}$ & $\begin{array}{l}\text { Indistinguishable } \\
\text { placebo }\end{array}$ & $\begin{array}{l}\text { - Development of allergic diseases in } \\
\text { children. } \\
\text { Main outcome: probiotic } \\
\text { supplementation prevents infant eczema }\end{array}$ & $\begin{array}{l}24 \text { months after } \\
\text { delivery }\end{array}$ & Not observed \\
\hline
\end{tabular}


Table 2. Cont.

\begin{tabular}{|c|c|c|c|c|c|c|c|}
\hline Author, Year & Study Design & Study Population & $\begin{array}{l}\text { Intervention } \\
\text { Strain } \\
\text { Dose (D) } \\
\text { Start of Treatment (S) } \\
\text { End of Treatment (E) } \\
\end{array}$ & Placebo & Outcomes Evaluations & Follow-Up & Side Effects \\
\hline $\begin{array}{l}\text { Kim et al., } 2010 \\
\text { [69] }\end{array}$ & $\begin{array}{c}\text { Randomized, } \\
\text { double-blind, } \\
\text { placebo-controlled trial }\end{array}$ & $\begin{array}{l}112 \text { pregnant } \\
\text { women }\end{array}$ & $\begin{array}{l}\text { Bifidobacterium bifidum } \mathrm{BGN4} \text {, B. lactis AD011, and } \\
\text { Lactobacillus acidophilus AD031 } \\
\text { D: } 1.6 \times 10^{9} \text { CFU for each probiotic } \\
\text { S: } 4-8 \text { weeks before delivery (to mothers) } \\
\text { E: until } 6 \text { months after delivery (to mothers during } \\
\text { breastfeeding and to infants) }\end{array}$ & $\begin{array}{l}\text { Indistinguishable } \\
\text { powder }\end{array}$ & $\begin{array}{l}\text { Assess the occurrence of eczema } \\
\text { Main outcome: probiotics administration } \\
\text { reduces the incidence of eczema in } \\
\text { children }\end{array}$ & $\begin{array}{l}12 \text { months after } \\
\text { delivery }\end{array}$ & $\begin{array}{l}\text { adverse events } \\
\text { minor and } \\
\text { non-specific of } \\
\text { probiotics use }\end{array}$ \\
\hline $\begin{array}{l}\text { Niers et al., } 2009 \\
\quad[70]\end{array}$ & $\begin{array}{l}\text { Double-blind, } \\
\text { randomized, } \\
\text { placebo-controlled trial }\end{array}$ & $\begin{array}{l}136 \text { pregnant } \\
\text { women }\end{array}$ & $\begin{array}{l}\text { Bifidobacterium bifidum, Bifidobacterium lactis, and } \\
\text { Lactococcus lactis } \\
\text { D: } 1 \times 10^{9} \text { CFU of each strain } \\
\text { S: last } 6 \text { weeks of pregnancy (to mothers) } \\
\text { E: } 12 \text { months after delivery (to infants) }\end{array}$ & $\begin{array}{l}\text { Indistinguishable } \\
\text { powder }\end{array}$ & $\begin{array}{l}\text { - Development of allergic diseases in } \\
\text { infants } \\
\text { - Molecular analysis of fecal microbiota } \\
\text { in infants } \\
\text { - Cytokine analysis in infants } \\
\text { Main outcome: probiotics administration } \\
\text { reduces the incidence of eczema in } \\
\text { children at 3rd month of life }\end{array}$ & $\begin{array}{l}24 \text { months after } \\
\text { delivery }\end{array}$ & Not observed \\
\hline $\begin{array}{l}\text { Simpson et al., } \\
\quad 2015 \text { [71] }\end{array}$ & $\begin{array}{l}\text { Randomised controlled } \\
\text { trial }\end{array}$ & $\begin{array}{l}415 \text { pregnant } \\
\text { women }\end{array}$ & $\begin{array}{l}\text { Probiotic milk: Lactobacillus rhamnosus GG, L. acidophilus } \\
\text { La-5 and Bifidobacterium animalis subsp. lactis Bb-12 } \\
\text { D: } 5 \times 10^{10} \mathrm{CFU} \text { of Lactobacillus rhamnosus and } \\
\text { Bifidobacterium animalis and } 5 \times 10^{9} \mathrm{CFU} \text { of L. } \\
\text { acidophilus La-5 } \\
\text { S: from } 36 \text { weeks gestation (to mothers) } \\
\text { E: until } 3 \text { months postpartum (during breast-feeding) }\end{array}$ & Placebo milk & $\begin{array}{l}\text { Development of allergic diseases in } \\
\text { infants } \\
\text { Main outcome: probiotics administration } \\
\text { reduces the incidence of atopic } \\
\text { dermatitis }\end{array}$ & $\begin{array}{c}6 \text { years after } \\
\text { delivery }\end{array}$ & Not observed \\
\hline
\end{tabular}




\section{Brain-Gut Microbiota Axis}

The microbiota plays an important role in the interaction between the brain and the enteric nervous system, known as the "brain-gut microbiota axis". Thanks to this axis, information from the Central nervous system can influence the motor, secretory, and sensitive functions of the gastrointestinal tract; conversely, visceral signals from the gut can modulate brain activity, mood, and behavior [7]. The gut-brain dialogue involves neuro-immuno-endocrine mediators [74].

It is believed that alterations in the microbiota gut-brain axis are associated with the onset of irritable bowel syndrome (IBS) or functional gastrointestinal (GI) disorders [75], and might be implicated in autism spectrum disorders (ASDs) [76-78], anxiety-depressive behaviors [76,79-81], and chronic pain [82]. However, the sites, the pathways and molecular mechanisms responsible for these alterations must be better defined.

Different models have been used to define the gut brain axis (GBA), including gut microbial perturbation by antibiotics and probiotics, fecal microbial transplantation, and mice who lived without any exposure to microorganisms (germ-free, GF) [83]. GF animals were born by Caesarean section and lived in aseptic conditions.

There is supporting evidence that metabolites derived from maternal gut microbiome modulate the neurotransmitter, synaptic, and neurotrophic signaling systems, thus influencing fetal brain development [84]. Petterson et al. underline that "healthy" intestinal microbiota is crucial for the programming of mammalian neurodevelopment and later adult behavior. This study suggests that early microbial colonization influences the expression of synaptic-related proteins (e.g., synaptophysin, which is an indicator of synaptogenesis), signaling pathways, and neurotransmitter turnover, that could modulate the synaptic transmission influencing motor control and emotional behavior in adults [85].

It has also been reported that maternal separation (MS) in rodents induced dysbiosis and brain and behavioral changes [86]. MS triggers depression and anxiety-like behavior [87,88], hyper-responsiveness of the HPA axis [89], increased intestinal permeability [90-92], and visceral hypersensitivity [93].

Maternal stress and MS might be implicated with modifications of gut brain axis [94,95] and probiotics seem to improve those gut and brain changes caused by perinatal stressors [96-98]. In different studies, it was observed that postnatal microbial colonization regulates an adequate HPA response to stress [99] and the hippocampal serotoninergic system [100]. It was also described a decrease in depression and anxiety-like behavior after the administration of oral probiotics in mice $[96,101,102]$ and humans $[103,104]$ with normal gut microbiota.

Furthermore, the short-chain fatty acids (SCFA s) generated by the colonic microbiota represent a significant source of energy for the gastrointestinal cells. In this regard, colonocytes from germ-free C57BL/ 6 rodents showed lower energy statuses than normally-raised mice [105].

Additionally, the loss of intestinal-generated SCFAs induces metabolic changes that may affect neurodevelopment and alter mechanisms associated with feeding behavior and metabolism [83].

Indeed, recent studies compare ingestive behavior between mice with gut microbial composition and GF, suggesting that gut microbioma modulate feeding behavior. GF mice showed lower blood levels of leptin and ghrelin, and a higher inclination for lipids, justified by the increased expression of oral receptors for fats and a decreased one for gut fatty-acid receptors [106].

Furthermore, it was observed that bifidobacterium B. longum 1714 improves cognition in mice [107]. Additionally, the administration of a probiotic mixture containing L. paracasei DSM 24733, L. plantarum DSM 24730, L. acidophilus DSM 24735, and L. delbrueckii subsp. bulgaricus DSM 24734), three strains of bifidobacteria (B. longum DSM 24736, B. breve DSM 24732, and B. infantis DSM 24737), and one strain of Streptococcus thermophilus DSM 24731 (Danisco-Dupont, WI, USA, currently sold in Continental Europe and USA under the brand Vivomixx ${ }^{\circledR}$ and Visbiome ${ }^{\circledR}$, respectively) to aged animals induced a reduction of the age-related attenuation of LTP through modifications of the gut microbiota [108]. These results are interesting but translational studies in humans are necessary. 


\section{Probiotics and Functional Gastrointestinal Disorders}

Probiotics have an important role in the maturation and health of the intestinal tract. The composition of gut microbiota is involved in the development of gastrointestinal functions, particularly in the gut-brain axis, and participates in emitting and receiving signals to and from the brain [109]. This connection occurs with different mechanisms: through the release of cytokines and chemokine (immune pathway), through neural pathways, and through the production of intestinal neuroendocrine factors (endocrine pathway) [6]. Therefore, through changes of the microbiota, bidirectional relationships between the gut and brain are modified, thus influencing the pathogenesis of functional gastrointestinal disorders. The most common diseases in early life are infantile colic, a benign and functional gastrointestinal disorder that affects around $20 \%$ of young infants. Colic is associated with parental frustration and anxiety, and resolves spontaneously after the first three to four months of life. Although infantile colic is a self-resolving condition, it implies long-term effects on a child's behavior, sleep, and allergies [110].

According to the Rome IV criteria for functional gastrointestinal disorders, infantile colic is diagnosed in infants younger than 4 months of age if the following symptoms occur: paroxysms of irritability, fussing or crying that starts and stops without obvious cause; episodes lasting 3 or more hours per day and occurring at least 3 days per week for at least 1 week; and no failure to thrive [111].

Infantile colic presents a multifactorial aetiology, but the cause remains unclear. However, some causative mechanisms have been suggested like behavioral, food allergies and hypersensitivities, immaturity of gut function, and dysmotility [112].

An extensive number of possible factors have been hypothesized, like increased painful intestinal contractions, lactose intolerance, food hypersensitivity, gas, parental misinterpretation of the normal crying pattern, and altered gut microbiota (dysbiosis). In the management of infantile colic, many therapies are used, such as dietary, pharmacological, and behavioral interventions. However, data on their effectiveness are limited. Dysbiosis may play an important role in the pathogenesis of infantile colic, and gut microbiota modification with probiotics can have advantages on the management of infantile colic [113].

Partty et al. have conducted a randomized, double-blind, prospective study based on the administration of L. rhamnosus GG (ATCC 53103) or placebo to mothers daily for 4 weeks before expected delivery, and subsequently to the child or the mother, if breast-feeding, for 6 months, to evaluate the influence on the appearance of functional gastrointestinal disorders.

They hypothesized that colic crying, typical of the perinatal period, was associated with functional gastrointestinal disorders later in childhood.

Their 13-year follow-up study showed that administration of L. rhamnosus GG (ATCC 53103) does not affect the appearance of functional gastrointestinal disorders later in childhood, but suggests that different probiotics or probiotic combinations may be needed [114]. (Table 3).

It has been shown that probiotic administration to women during pregnancy and lactation can change the composition of breast milk, and consequently, its immunomodulatory molecular composition, bestowing benefits on the child in the form of reduced instances of gastrointestinal disorders.

A study conducted in 2013 showed an increase in breast milk of anti-inflammatory molecules such as TGF-B and IL-10 in supplemented mothers compared to the control group. Indeed, maternal probiotic supplementation leads to an increase of the TGF-B, which stimulates gut maturity, influencing IgA production and oral tolerance induction, and that seems to improve gastrointestinal functional symptoms in infants [115].

In a recent study, Baldassarre et al. have demonstrated that the use of a probiotic mixture (L. paracasei DSM 24733, L. plantarum DSM 24730, L. acidophilus DSM 24735, and L. delbrueckii subsp. bulgaricus DSM 24734), three strains of bifidobacteria (B. longum DSM 24736, B. breve DSM 24732, and B. infantis DSM 24737), and one strain of Streptococcus thermophilus DSM 24731, Vivomixx ${ }^{\circledR}$, 
Danisco-Dupont, WI, USA) appears safe and reduces inconsolable crying in exclusively breastfed infants with infantile colic [116].

Many studies have also been conducted on the prophylactic use of probiotics in the first months of life to treat breastfed infants with colic. In particular, benefits of the use of Lactobacillus reuteri on functional gastrointestinal disorders have been studied.

Gutiérrez-Castrellón et al. [117] have demonstrated the superiority of the use of L. reuteri DSM 17938 with a dose of $10^{8} \mathrm{CFU} /$ day for 21 to 28 days to significantly reduce the duration of crying episodes during the day.

Recently, Indrio et al. [118] have suggested that oral supplementation of L. reuteri, for the first three months of life, not only reduces the probability of colic episodes and other functional gastrointestinal disorders, like gastroesophageal reflux and constipation, but also the number of visits and hospitalizations.

In conclusion, L. reuteri DSM17938 is effective, and may be recommended for breastfed infants with colic, while its role in formula-fed infants requires further study [119].

\section{Safety of Probiotics in Pregnancy and Neonatal Period}

The early supplementation of probiotics in the perinatal and postnatal periods seems to have a positive impact on future health of infants. In this article we have shown the beneficial effects of probiotics in preventing infections before and after delivery and atopy in children. However, to define the possible role of the early administration of probiotics on the development of the nervous system of newborns, future studies and randomized trials are required. The use of probiotics is usually considered safe, even in first months of life. Despite the large use of probiotics during pregnancy and perinatal period, there are few studies that tested their safety during this period. Development of infections or other adverse effects in adult patients after the use of probiotics are rarely reported and often involve immunocompromised patients $[120,121]$. Allen et al., in a randomized, double-blinded, placebo-controlled trial, have tested the possible adverse effects of the administration of a probiotics mixture to pregnant women and to their infants after the birth. In this study, none of the adverse effects was attributed to the supplementation of probiotics [122]. Moreover, Baldassarre et al., in a prospective, double-blinded, randomized, controlled trial, confirmed that the early administration of probiotics during pregnancy has no side effects in mothers or in infants [115]. In addition, Luoto et al. in a clinical trial, involving 256 pregnant women and their offspring, showed no side effects in mothers and children after the administration of Lactobacillus rhamnosus GG and Bifidobacterium lactis Bb12 probiotics mixture [123]. In contrast, Kuitunen et al. have suggested that the early supplementation of probiotics negatively influences hematologic values in infants. In this trial, children supplemented with probiotics before and after the birth have significantly lower haemoglobin levels compared to the placebo group at 6th month of life. This effect is transient, and may be due to a potential inflammation of the intestinal mucosa probably caused by probiotics [124] (Table 4). Future studies are needed to confirm the total safety of the use of probiotics during pregnancy and in the early stages of life. 
Table 3. Probiotics and functional gastrointestinal disorders.

\begin{tabular}{|c|c|c|c|c|c|c|c|}
\hline Author, Year & Study Design & Study Population & $\begin{array}{l}\text { Intervention } \\
\text { Strain } \\
\text { Dose (D) } \\
\text { Start of Treatment (S) } \\
\text { End of Treatment (E) }\end{array}$ & Placebo & Outcomes Evaluations & Follow-Up & Side Effects \\
\hline $\begin{array}{c}\text { Partty et al., } 2013 \\
\text { [114] }\end{array}$ & $\begin{array}{l}\text { Randomized } \\
\text { Double-blind } \\
\text { Prospective } \\
\text { Follow up }\end{array}$ & 159 women & $\begin{array}{l}\text { L. rhamnosus GG (ATCC 53103) } \\
\text { D: not available } \\
\text { S: } 4 \text { weeks before expected delivery } \\
\text { E: } 6 \text { months after delivery to child or } \\
\text { to the mother if breast-feeding }\end{array}$ & $\begin{array}{l}\text { Indistinguishable } \\
\text { powder }\end{array}$ & $\begin{array}{l}\text { Functional gastrointestinal disorders } \\
\text { Main outcome: administration of L. rhamnosus GG (ATCC } \\
\text { 53103) does not affect the appearance of functional } \\
\text { gastrointestinal disorders later in childhood }\end{array}$ & 13 years & Not observed \\
\hline $\begin{array}{l}\text { Baldassarre et al., } \\
2016[115]\end{array}$ & $\begin{array}{l}\text { Prospective } \\
\text { Double-blind } \\
\text { Randomized } \\
\text { Controlled }\end{array}$ & $\begin{array}{c}66 \text { women aged } \\
18-44\end{array}$ & $\begin{array}{l}\text { Probiotic mixture: } \\
\text { L. paracasei DSM 24733, } \\
\text { L. plantarum DSM 24730, } \\
\text { L. acidophilus DSM 24735, } \\
\text { L. delbrueckii subsp. bulgaricus DSM } \\
\text { 24734, } \\
\text { B. longum DSM 24736, } \\
\text { B. breve DSM 24732, } \\
\text { B. infantis DSM 24737, } \\
\text { Streptococcus thermophilus DSM } 24731 \\
\text { D: } 900 \text { billion } \\
\text { S: } 4 \text { weeks before expected delivery } \\
\text { E: } 4 \text { weeks after delivery }\end{array}$ & $\begin{array}{l}\text { Indistinguishable } \\
\text { powder }\end{array}$ & $\begin{array}{l}\text { - cytokine profile and secretory IgA in breast milk } \\
\text { - lactoferrin and sIgA levels in stool samples of newborns } \\
\text { - newborn gastrointestinal symptoms } \\
\text { - neonatal growth pattern } \\
\text { Main outcome: maternal supplementation with probiotic } \\
\text { modulates breast milk cytokines pattern in newborns and } \\
\text { improves gastrointestinal functional symptoms }\end{array}$ & $\begin{array}{l}4 \text { weeks after } \\
\text { delivery }\end{array}$ & Not observed \\
\hline
\end{tabular}


Table 4. Safety of probiotics in pregnancy and neonatal period.

\begin{tabular}{|c|c|c|c|c|c|c|c|}
\hline Author, Year & Study Design & Study Population & $\begin{array}{l}\text { Intervention } \\
\text { Strain } \\
\text { Dose }(\mathrm{D}) \\
\text { Start of Treatment (S) } \\
\text { End of Treatment (E) } \\
\end{array}$ & Placebo & Outcomes Evaluations & Follow-Up & Side Effects \\
\hline $\begin{array}{l}\text { Luoto et al., } 2010 \\
\text { [123] }\end{array}$ & $\begin{array}{c}\text { Double-blind, } \\
\text { placebo-controlled } \\
\text { study }\end{array}$ & $\begin{array}{l}256 \text { pregnant } \\
\text { women }\end{array}$ & $\begin{array}{l}\text { Lactobacillus rhamnosus GG and Bifidobacterium lactis } \\
\text { Bb12 } \\
\text { D: } 10^{10} \text { colony-forming unit (CFU)/d each } \\
\text { S: first trimester of pregnancy (to mothers) } \\
\text { E: to the end of exclusive breastfeeding }\end{array}$ & $\begin{array}{l}\text { Indistinguishable } \\
\text { placebo capsule }\end{array}$ & $\begin{array}{l}\text { - Safety and efficacy of probiotic in mothers and } \\
\text { infants } \\
\text { Main outcome: probiotics supplementation reduced } \\
\text { the frequency of gestational diabetes mellitus with a } \\
\text { normal duration of pregnancies and no adverse } \\
\text { events in mothers or children }\end{array}$ & $\begin{array}{l}24 \text { months after } \\
\text { delivery }\end{array}$ & Not observed \\
\hline $\begin{array}{l}\text { Allen et al., } 2010 \\
{[\text { [122] }}\end{array}$ & $\begin{array}{c}\text { Randomized, } \\
\text { double-blinded, } \\
\text { placebo-controlled } \\
\text { trial }\end{array}$ & $\begin{array}{l}454 \text { pregnant } \\
\text { women }\end{array}$ & $\begin{array}{l}\text { Two strains of lactobacilli (Lactobacillus salivarius } \\
\text { CUL61 and Lactobacillus paracasei CULO8) and } \\
\text { bifidobacteria (Bifidobacterium animalis subsp. lactis } \\
\text { CUL34 and Bifidobacterium bifidum CUL20) } \\
\text { D: a total of } 1 \times 10^{10} \mathrm{CFU} / \mathrm{d} \\
\text { S: last month of pregnancy (to mother) } \\
\text { E: until } 6 \text { months of life (to infants) }\end{array}$ & $\begin{array}{l}\text { Indistinguishable } \\
\text { placebo capsule }\end{array}$ & $\begin{array}{l}\text { - Symptoms and adverse effects in mother and } \\
\text { infants } \\
\text { Main outcome: No side effects were attributed to } \\
\text { probiotics supplementation }\end{array}$ & $\begin{array}{l}24 \text { months after } \\
\text { delivery }\end{array}$ & Not observed \\
\hline $\begin{array}{l}\text { Kuitunen et al., } \\
2009 \text { [124] }\end{array}$ & $\begin{array}{l}\text { Prospective } \\
\text { randomized } \\
\text { controlled trial }\end{array}$ & $\begin{array}{l}1223 \text { pregnant } \\
\text { women }\end{array}$ & $\begin{array}{l}\text { Lactobacillus rhamnosus GG (ATCC 53103) } \\
5 \times 10^{9} \mathrm{CFU}, \mathrm{L} \text { rhamnosus LC705 } \\
\text { (DSM 7061) } 5 \times 10^{9} \mathrm{CFU}, \text { Bifidobacterium breve Bb99 } \\
\text { (DSM 13692) } 2 \times 10^{8} \mathrm{CFU} \text {, and Propionibacterium } \\
\text { freudenreichii ssp } \\
\text { shermanii JS (DSM 7076) } 2 \times 10^{9} \mathrm{CFU} \\
\text { S: } 4 \text { weeks } \\
\text { before delivery (to mothers) } \\
\text { E: until } 6 \text { months of life (to infants) }\end{array}$ & $\begin{array}{l}\text { Indistinguishable } \\
\text { placebo }\end{array}$ & $\begin{array}{l}\text { - Safety and efficacy of probiotic in mothers and } \\
\text { infants } \\
\text { - Blood and faecal samples taken from children } \\
\text { Main outcome: Infants in the probiotic group have } \\
\text { lower haemoglobin levels compared to the placebo } \\
\text { group at 6th month of life }\end{array}$ & $\begin{array}{l}24 \text { months after } \\
\text { delivery }\end{array}$ & $\begin{array}{l}\text { lower } \\
\text { haemoglobin } \\
\text { levels at } 6 \text { th month } \\
\text { of life }\end{array}$ \\
\hline
\end{tabular}




\section{Conclusions}

In the last 20 years, it has been shown that the constitution of the human microbiome is conditioned by multiple elements such as genetic heritage, prematurity, cesarean section, kind of infant nutrition, administration of probiotics or antibiotics, perinatal stressors, and infections. Further studies demonstrated that a normal intestinal microbiota takes part in the induction of the immune tolerance $[125,126]$. Alterations of the microbiota are associated with the development of many pathological states like infantile colic, inflammatory bowel disease, necrotizing enterocolitis, asthma, atopic diseases, celiac disease, diabetes, mood disorders, and autism spectrum disorders. Additional studies are needed to attest that probiotics could have a protective function against the onset and the progression of these diseases. Nowadays there is no standard recommendation for performing targeted supplementation in individual patients.

Studies suggest that the microbiota may influence immunologic and inflammatory systemic responses, and thus, modulate the onset of sensitization and allergy.

In 2015, the WAO guidelines on the prevention of allergies recommends using probiotics in: (a) pregnant women at high risk for having an allergic child; (b) women who breastfeed infants at high risk of developing allergies; and (c) infants at high risk of developing allergies [73].

These are the only recommendations by the Scientific Community for using probiotics as a preventive intervention for diseases during pregnancy and perinatal period, despite the many studies demonstrating clinical benefits from the administration of probiotics in pregnancy and the perinatal period. So, it is important to obtain more data about the exact composition of microbiomes and the alterations which occur in specific diseases. It is also important to underline that the security and effectiveness of findings attributable to one single probiotic product cannot be applied to other probiotic formulations, especially if the product is administered to patients such as pregnant women and newborns; this is a serious task, and therapeutic discomfort that multi-strain probiotic formulations lack generic names, because they are food supplements. Many clinicians and patients are unaware that deficiencies in the regulation of probiotics mean that the formulations sold under these medically-recognized brand names may no longer be the same as the original products on which the clinical efficacy and safety evidence is based. FAO/WHO guidelines for probiotics state that proper nomenclature and strain designation are required on a probiotic product. Without proper identification of the strains and/or of the clarification of the origin of the product such as manufacturing site, the clinical evidence is erroneously transferred from one product to another. This is the reason why limiting the information to probiotic genera/species is not the best choice [127], and more stringent quality control of probiotics is required [128].

Author Contributions: M.E.B. and V.P. drafted the initial manuscript and revised the final manuscript. A.A. and S.P. made substantial contributions to data acquisition. A.D.M., P.M., M.F. and N.L. reviewed and revised the manuscript. All authors approved the final manuscript as submitted.

Funding: This research received no external funding.

Conflicts of Interest: The authors declare no conflict of interest.

\section{References}

1. Hillman, E.T.; Yao, H.L.T.; Nakatsu, C.H. Microbial Ecology along the Gastrointestinal Tract. Microbes Environ. 2017, 32, 300-313. [CrossRef] [PubMed]

2. O'Hara, A.M.; Shanahan, F. The gut flora as a forgotten organ. EMBO Rep. 2006, 7, 688-693. [CrossRef] [PubMed]

3. Lay, C.; Sutren, M.; Rochet, V.; Saunier, K.; Doré, J.; Rigottier-Gois, L. Design and validation of 16S rDNA probes to enumerate members of the Clostridium leptum subgroup in human faecal microbiota. Environ. Microbiol. 2005, 7, 933-946. [CrossRef] [PubMed] 
4. Gill, S.R.; Pop, M.; Deboy, R.T.; Eckburg, P.B.; Turnbaugh, P.J.; Samuel, B.S.; Gordon, J.I.; Relman, D.A.; Fraser-Liggett, C.M.; Nelson, K.E. Metagenomic analysis of the human distal gut microbiome. Science 2006, 312, 1355-1359. [CrossRef] [PubMed]

5. Pickard, J.M.; Zeng, M.Y.; Caruso, R.; Núñez, G. Gut microbiota: Role in pathogen colonization, immune responses, and inflammatory disease. Immunol. Rev. 2017, 279, 70-89. [CrossRef] [PubMed]

6. Indrio, F.; Riezzo, G.; Raimondi, F.; Di Mauro, A.; Francavilla, R. Microbiota Involvement in the Gut-Brain Axis. JPGN 2013, 57, S11-S15. [CrossRef]

7. Baldassarre, M.E.; Bellantuono, L.; Mastromarino, P.; Miccheli, A.; Fanelli, M.; Laforgia, N. Gut and Breast Milk Microbiota and Their Role in the Development of the Immune Function. Curr. Pediatr. Rep. 2014, 2, 218-226. [CrossRef]

8. Escherich, T. The intestinal bacteria of the neonate and breast-fed infant 1885. Rev. Infect. Dis. 1989, 11, 352-356. [CrossRef] [PubMed]

9. Jiménez, E.; Marín, M.L.; Martín, R.; Odriozola, J.M.; Olivares, M.; Xaus, J.; Fernández, L.; Rodríguez, J.M. Is meconium from healthy newborns actually sterile? Res. Microbiol. 2008, 159, 187-193. [CrossRef] [PubMed]

10. Collado, M.C.; Rautava, S.; Aakko, J.; Isolauri, E.; Salminen, S. Human gut colonisation may be initiated in utero by distinct microbial communities in the placenta and amniotic fluid. Sci. Rep. 2016, 6, 23129. [CrossRef] [PubMed]

11. Aagaard, K.; Ma, J.; Antony, K.M.; Ganu, R. The placenta harbors a unique microbiome. Sci. Transl. Med. 2014, 6, 237ra65. [CrossRef] [PubMed]

12. Perez, P.F.; Doré, J.; Leclerc, M.; Levenez, F.; Benyacoub, J.; Serrant, P.; Segura-Roggero, I.; Schiffrin, E.J.; Donnet-Hughes, A. Bacterial imprinting of the neonatal immune system: Lessons from maternal cells? Pediatrics 2007, 119, e724-e732. [CrossRef] [PubMed]

13. Ardissone, A.N.; de la Cruz, D.M.; Davis-Richardson, A.G.; Rechcigl, K.T.; Li, N.; Drew, J.C.; Murgas-Torrazza, R.; Sharma, R.; Hudak, M.L.; Triplett, E.W.; et al. Meconium microbiome analysis identifies bacteria correlated with premature birth. PLoS ONE 2014, 9, e90784. [CrossRef] [PubMed]

14. Walker, W.A. The importance of appropriate initial bacterial colonization of the intestine in newborn, child and adult health. Pediatr. Res. 2017, 82, 387-395. [CrossRef] [PubMed]

15. Sirilun, S.; Takahashi, H.; Boonyaritichaikij, S.; Chaiyasut, C.; Lertruangpanya, P.; Koga, Y.; Mikami, K. Impact of maternal bifidobacteria and the mode of delivery on Bifidobacterium microbiota in infants. Benef. Microbes 2015, 6, 767-774. [CrossRef] [PubMed]

16. Lundgren, S.N.; Madan, J.C.; Emond, J.A.; Morrison, H.G.; Christensen, B.C.; Karagas, M.R.; Hoen, A.G. Maternal diet during pregnancy is related with the infant stool microbiome in a delivery mode-dependent manner. Microbiome 2018, 6, 109. [CrossRef] [PubMed]

17. Azad, M.B.; Konya, T.; Maughan, H.; Guttman, D.S.; Field, C.J.; Chari, R.S.; Sears, M.R.; Becker, A.B.; Scott, J.A.; Kozyrskyj, A.L. Gut microbiota of healthy Canadian infants: Profiles by mode of delivery and infant diet at 4 months. CMAJ 2013, 185, 385-394. [CrossRef] [PubMed]

18. Wopereis, H.; Oozeer, R.; Knipping, K.; Belzer, C.; Knol, J. The first thousand days-Intestinal microbiology of early life: Establishing a symbiosis. Pediatr. Allergy Immunol. 2014, 25, 428-438. [CrossRef] [PubMed]

19. Van Zwol, A.; Van Den Berg, A.; Knol, J.; Twisk, J.W.; Fetter, W.P.; Van Elburg, R.M. Intestinal microbiota in allergic and nonallergic 1 year-old very low birth weight infants after neonatal glutamine supplementation. Acta Paediatr. 2010, 99, 1868-1874. [CrossRef] [PubMed]

20. Mårild, K.; Stephansson, O.; Montgomery, S.; Murray, J.A.; Ludvigsson, J.F. Pregnancy outcome and risk of celiac disease in offspring: A nationwide case-control study. Gastroenterology 2012, 142, 39-45. [CrossRef] [PubMed]

21. Thavagnanam, S.; Fleming, J.; Bromley, A.; Shields, M.D.; Cardwell, C.R. A meta-analysis of the association between Caesarean section and childhood asthma. Clin. Exp. Allergy 2008, 38, 629-633. [CrossRef] [PubMed]

22. Imoto, N.; Morita, H.; Amanuma, F.; Maruyama, H.; Watanabe, S.; Hashiguchi, N. Maternal antimicrobial use at delivery has a stronger impact than mode of delivery on bifidobacterial colonization in infants: A pilot study. J. Perinatol. 2018, 15, 16. [CrossRef] [PubMed]

23. Schumann, A.; Nutten, S.; Donnicola, D.; Comelli, E.M.; Mansourian, R.; Cherbut, C.; Corthesy-Theulaz, I.; Garcia-Rodenas, C. Neonatal antibiotic treatment alters gastrointestinal tract developmental gene expression and intestinal barrier transcriptome. Physiol. Genom. 2005, 23, 235-245. [CrossRef] [PubMed] 
24. Taft, D.H.; Ambalavanan, N.; Schibler, K.R.; Yu, Z.; Newburg, D.S.; Ward, D.V.; Morrow, A.L. Intestinal microbiota of preterm infants differ over time and between hospitals. Microbiome 2014, 2, 36. [CrossRef] [PubMed]

25. Gritz, E.C.; Bhandari, V. The Human Neonatal Gut Microbiome: A Brief Review. Front. Pediatr. $2015,3,17$. [PubMed]

26. Magne, F.; Abély, M.; Boyer, F.; Morville, P.; Pochart, P.; Suau, A. Low species diversity and high interindividual variability in faeces of preterm infants as revealed by sequences of 16S rRNA genes and PCR-temporal temperature gradient gel electrophoresis profiles. FEMS Microbiol. Ecol. 2006, 57, 128-138. [CrossRef] [PubMed]

27. Neu, J. Gastrointestinal development and meeting the nutritional needs of premature infants. Am. J. Clin. Nutr. 2007, 85, 629S-634S. [CrossRef] [PubMed]

28. Meis, P.J.; Goldenberg, R.L.; Mercer, B.; Moawad, A.; Das, A.; McNellis, D.; Johnson, F.; Iams, J.D.; Thom, E.; Andrews, W.W. The preterm prediction study: Significance of vaginal infections. National Institute of Child Health and Human Development Maternal-Fetal Medicine Units Network. Am. J. Obstet. Gynecol. 1995, 173, 1231-1235. [CrossRef]

29. Goldenberg, R.L.; Hauth, J.C.; Andrews, W.W. Intrauterine infection and preterm delivery. N. Engl. J. Med. 2000, 342, 1500-1507. [CrossRef] [PubMed]

30. Le Huërou-Luron, I.; Blat, S.; Boudry, G. Breast-v. formula-feeding: Impacts on the digestive tract and immediate and long-term health effects. Nutr. Res. Rev. 2010, 23, 23-36. [CrossRef] [PubMed]

31. Mastromarino, P.; Capobianco, D.; Campagna, G.; Laforgia, N.; Drimaco, P.; Dileone, A.; Baldassarre, M.E. Correlation between lactoferrin and beneficial microbiota in breast milk and infant's feces. BioMetals 2014, 27, 1077-1086. [CrossRef] [PubMed]

32. Buccigrossi, V.; de Marco, G.; Bruzzese, E.; Ombrato, L.; Bracale, I.; Polito, G.; Guarino, A. Lactoferrin induces concentration-dependent functional modulation of intestinal proliferation and differentiation. Pediatr. Res. 2007, 61, 410-414. [CrossRef] [PubMed]

33. Oda, H.; Wakabayashi, H.; Yamauchi, K.; Abe, F. Lactoferrin and bifidobacteria. Biometals 2014, 27, $915-922$. [CrossRef] [PubMed]

34. Arrieta, M.C.; Stiemsma, L.T.; Dimitriu, P.A.; Thorson, L.; Russell, S.; Yurist-Doutsch, S.; Kuzeljevic, B.; Gold, M.J.; Britton, H.M.; Lefebvre, D.L.; et al. Early infancy microbial and metabolic alterations affect risk of childhood asthma. Sci. Transl. Med. 2015, 7, 307ra152. [CrossRef] [PubMed]

35. Donnet-Hughes, A.; Perez, P.F.; Doré, J.; Leclerc, M.; Levenez, F.; Benyacoub, J.; Serrant, P.; Segura-Roggero, I.; Schiffrin, E.J. Potential role of the intestinal microbiota of the mother in neonatal immune education. Proc. Nutr. Soc. 2010, 69, 407-415. [CrossRef] [PubMed]

36. Fernández, L.; Langa, S.; Martin, V.; Maldonado, A.; Jiménez, E.; Martin, R.; Rodríguez, J.M. The human milk microbiota: Origin and potential roles in health and disease. Pharmacol. Res. 2013, 69, 1-10. [CrossRef] [PubMed]

37. Bergmann, H.; Rodríguez, J.M.; Salminem, S.; Szajewska, H. Probiotics in human milk and prebiotico supplementation in infant nutrition: A workshop report. Br. J. Nutr. 2014, 112, 1119-1128. [CrossRef] [PubMed]

38. Newburg, D.S.; Walker, W.A. Protection of the neonate by the immune system of developing gut and of human milk. Pediatr. Res. 2007, 61, 2-8. [CrossRef] [PubMed]

39. Gregory, K.E.; Walker, W.A. Immunologic factors in human milk and disease prevention in the preterm infant. Curr. Pediatr. Rep. 2013, 1, 222-228. [CrossRef] [PubMed]

40. Jost, T.; Lacroix, C.; Braegger, C.P.; Chassard, C. New insights in gut microbiota establishment in healthy breast fed neonates. PLoS ONE 2012, 7, e44595. [CrossRef] [PubMed]

41. Schwartz, S.; Friedberg, I.; Ivanov, I.V.; Davidson, L.A.; Goldsby, J.S.; Dahl, D.B.; Herman, D.; Wang, M.; Donovan, S.M.; Chapkin, R.S. A metagenomic study of diet-dependent interaction between gut microbiota and host in infants reveals differences in immune response. Genome Biol. 2012, 13, r3. [CrossRef] [PubMed]

42. Furuta, G.; Walker, W.A. Non-immune defense mechanisms of the gastrointestinal tract. In Infections of the Gastrointestinal Tract; Blaser, M.J., Smith, P.D., Ravdin, J.I., Greenberg, H.B., Guerrant, R.L., Eds.; Raven Press Ltd.: New York, NY, USA, 1995; pp. 89-98. 
43. Chichlowski, M.; De Lartigue, G.; German, J.B.; Raybould, H.E.; Mills, D.A. Bifidobacteria isolated from infants and cultured on human milk oligosaccharides affect intestinal epithelial function. J. Pediatr. Gastroenterol. Nutr. 2012, 55, 321-327. [CrossRef] [PubMed]

44. Rautava, S.; Walker, W.A. Breatfeeding-An extrauterine link between mother and child. Breastfeed. Med. 2009, 4, 3-10. [CrossRef] [PubMed]

45. Arneth, B.M. Gut-brain axis biochemical signalling from the gastrointestinal tract to the central nervous system: Gut dysbiosis and altered brain function. Postgrad. Med. J. 2018, 94, 446-452. [CrossRef] [PubMed]

46. Lazar, V.; Ditu, L.M.; Pircalabioru, G.G.; Gheorghe, I.; Curutiu, C.; Holban, A.M.; Picu, A.; Petcu, L.; Chifiriuc, M.C. Aspects of Gut Microbiota and Immune System Interactions in Infectious Diseases, Immunopathology, and Cancer. Front. Immunol. 2018, 9, 1830. [CrossRef] [PubMed]

47. Konturek, P.C.; Haziri, D.; Brzozowski, T.; Hess, T.; Heyman, S.; Kwiecien, S.; Konturek, S.J.; Koziel, J. Emerging role of fecal microbiota therapy in the treatment of gastrointestinal and extra-gastrointestinal diseases. J. Physiol. Pharmacol. 2015, 66, 483-491. [PubMed]

48. Hua, X.; Goedert, J.J.; Pu, A.; Yu, G.; Shi, J. Allergy associations with the adult fecal microbiota: Analysis of the American Gut Project. EBioMedicine 2015, 3, 172-179. [CrossRef] [PubMed]

49. Vitali, B.; Cruciani, F.; Baldassarre, M.E.; Capursi, T.; Spisni, E.; Valerii, M.C.; Candela, M.; Turroni, S.; Brigidi, P. Dietary supplementation with probiotics during late pregnancy: Outcome on vaginal microbiota and cytokine secretion. BMC Microbiol. 2012, 12, 236. [CrossRef] [PubMed]

50. Gille, C.; Böer, B.; Marschal, M.; Urschitz, M.S.; Heinecke, V.; Hund, V.; Speidel, S.; Tarnow, I.; Mylonas, I.; Franz, A.; et al. Effect of probiotics on vaginal health in pregnancy. EFFPRO, a randomized controlled trial. Am. J. Obstet. Gynecol. 2016, 215, 608-e1. [PubMed]

51. Russell, N.J.; Seale, A.C.; O’Sullivan, C.; Le Doare, K.; Heath, P.T.; Lawn, J.E.; Bartlett, L.; Cutland, C.; Gravett, M.; Ip, M.; et al. Risk of Early-Onset Neonatal Group B Streptococcal Disease with Maternal Colonization Worldwide: Systematic Review and Meta-analyses. Clin. Infect. Dis. 2017, 65 (Suppl. 2), S152-S159. [CrossRef] [PubMed]

52. Verani, J.R.; McGee, L.; Schrag, S.J. Prevention of perinatal group B streptococcal disease-revised guidelines from CDC, 2010. MMWR Recomm. Rep. 2010, 59, 1-32. [PubMed]

53. Olsen, P.; Williamson, M.; Traynor, V.; Georgiou, C. The impact of oral probiotics on vaginal Group B Streptococcal colonisation rates in pregnant women: A pilot randomised control study. Women Birth 2018, 31, 31-37. [CrossRef] [PubMed]

54. Ho, M.; Chang, Y.Y.; Chang, W.C.; Lin, H.C.; Wang, M.H.; Lin, W.C.; Chiu, T.H. Oral Lactobacillus rhamnosus GR-1 and Lactobacillus reuteri RC-14 to reduce Group B Streptococcus colonization in pregnant women: A randomized controlled trial. Taiwan J. Obstet. Gynecol. 2016, 55, 515-518. [CrossRef] [PubMed]

55. Nelson, D.B.; Hanlon, A.; Nachamkin, I.; Haggerty, C.; Mastrogiannis, D.S.; Liu, C.; Fredricks, D.N. Early pregnancy changes in bacterial vaginosis-associated bacteria and preterm delivery. Paediatr. Perinat. Epidemiol. 2014, 28, 88-96. [CrossRef] [PubMed]

56. Myhre, R.; Brantsæter, A.L.; Myking, S.; Gjessing, H.K.; Sengpiel, V.; Meltzer, H.M.; Haugen, M.; Jacobsson, B. Intake of probiotic food and risk of spontaneous preterm delivery. Am. J. Clin. Nutr. 2011, 93, 151-157. [CrossRef] [PubMed]

57. Krauss-Silva, L.; Moreira, M.E.L.; Alves, M.B.; Braga, A.; Camacho, K.G.; Batista, M.R.R.; Almada-Horta, A.; Rebello, M.R.; Guerra, F. A randomised controlled trial of probiotics for the prevention of spontaneous preterm delivery associated with bacterial vaginosis: Preliminary results. Trials 2011, 12, 239. [CrossRef] [PubMed]

58. Hantoushzadeh, S.; Golshahi, F.; Javadian, P.; Khazardoost, S.; Aram, S.; Hashemi, S.; Mirarmandehi, B.; Borna, S. Comparative efficacy of probiotic yoghurt and clindamycin in treatment of bacterial vaginosis in pregnant women: A randomized clinical trial. J. Matern. Fetal Neonatal Med. 2012, 25, 1021-1024. [CrossRef] [PubMed]

59. Jarde, A.; Lewis-Mikhael, A.M.; Moayyedi, P.; Stearns, J.C.; Collins, S.M.; Beyene, J.; McDonald, S.D. Pregnancy outcomes in women taking probiotics or prebiotics: A systematic review and meta-analysis. BMC Pregnancy Childbirth 2018, 18, 14. [CrossRef] [PubMed]

60. De Brito, C.A.; Goldoni, A.L.; Sato, M.N. Immune adjuvants in early life: Targeting the innate immune system to overcome impaired adaptive response. Immunotherapy 2009, 1, 883-895. [CrossRef] [PubMed] 
61. West, C.; Rydén, P.; Lundin, D.; Engstrand, L.; Tulic, M.K.; Prescott, S.L. Gut microbiome and innate immune response patterns in IgE-associated eczema. Clin. Exp. Allergy 2015, 45, 1419-1429. [CrossRef] [PubMed]

62. Azad, M.B.; Kozyrskyj, A.L. Perinatal programming of asthma: The role of gut microbiota. Clin. Dev. Immunol. 2012, 2012, 932072. [CrossRef] [PubMed]

63. Mastromarino, P.; Capobianco, D.; Miccheli, A.; Praticò, G.; Campagna, G.; Laforgia, N.; Capursi, T.; Baldassarre, M.E. Administration of a multistrain probiotic product (VSL\#3) to women in the perinatal period differentially affects breast milk beneficial microbiota in relation to mode of delivery. Pharmacol Res. 2015, 95-96, 63-70.

64. Dotterud, C.K.; Storrø, O.; Johnsen, R.; Oien, T. Probiotics in pregnant women to prevent allergic disease: A randomized, double-blind trial. Br. J. Dermatol. 2010, 163, 616-623. [CrossRef] [PubMed]

65. Enomoto, T.; Sowa, M.; Nishimori, K.; Shimazu, S.; Yoshida, A.; Yamada, K.; Furukawa, F.; Nakagawa, T.; Yanagisawa, N.; Iwabuchi, N.; et al. Effects of bifidobacterial supplementation to pregnant women and infants in the prevention of allergy development in infants and on fecal microbiota. Allergol. Int. 2014, 63, 575-585. [CrossRef] [PubMed]

66. Wickens, K.; Barthow, C.; Mitchell, E.A.; Stanley, T.V.; Purdie, G.; Rowden, J.; Kang, J.; Hood, F.; van den Elsen, L.; Forbes-Blom, E.; et al. Maternal supplementation alone with Lactobacillus rhamnosus HN001 during pregnancy and breastfeeding does not reduce infant eczema. Pediatr. Allergy Immunol. 2018, 29, 296-302. [CrossRef] [PubMed]

67. Ou, C.Y.; Kuo, H.C.; Wang, L.; Hsu, T.Y.; Chuang, H.; Liu, C.A.; Chang, J.C.; Yu, H.R.; Yang, K.D. Prenatal and postnatal probiotics reduces maternal but not childhood allergic diseases: A randomized, double-blind, placebo-controlled trial. Clin. Exp. Allergy 2012, 42, 1386-1396. [CrossRef] [PubMed]

68. Rautava, S.; Kainonen, E.; Salminen, S.; Isolauri, E. Maternal probiotic supplementation during pregnancy and breast-feeding reduces the risk of eczema in the infant. J. Allergy Clin. Immunol. 2012, 130, 1355-1360. [CrossRef] [PubMed]

69. Kim, J.Y.; Kwon, J.H.; Ahn, S.H.; Lee, S.I.; Han, Y.S.; Choi, Y.O.; Lee, S.Y.; Ahn, K.M.; Ji, G.E. Effect of probiotic mix (Bifidobacterium bifidum, Bifidobacterium lactis, Lactobacillus acidophilus) in the primary prevention of eczema: A double-blind, randomized, placebo-controlled trial. Pediatr. Allergy Immunol. 2010, 21, e386-e393. [CrossRef] [PubMed]

70. Niers, L.; Martín, R.; Rijkers, G.; Sengers, F.; Timmerman, H.; van Uden, N.; Smidt, H.; Kimpen, J.; Hoekstra, M. The effects of selected probiotic strains on the development of eczema (the PandA study). Allergy 2009, 64, 1349-1358. [CrossRef] [PubMed]

71. Simpson, M.R.; Dotterud, C.K.; Storrø, O.; Johnsen, R.; Øien, T. Perinatal probiotic supplementation in the prevention of allergy related disease: 6 year follow up of a randomised controlled trial. BMC Dermatol. 2015, 15, 13. [CrossRef] [PubMed]

72. Rø, A.D.B.; Simpson, M.R.; Rø, T.B.; Storrø, O.; Johnsen, R.; Videm, V.; Øien, T. Reduced Th22 cell proportion and prevention of atopic dermatitis in infants following maternal probiotic supplementation. Clin. Exp. Allergy 2017, 47, 1014-1021. [CrossRef] [PubMed]

73. Fiocchi, A.; Pawankar, R.; Cuello-Garcia, C.; Ahn, K.; Al-Hammadi, S.; Agarwal, A.; Beyer, K.; Burks, W.; Canonica, G.W.; Ebisawa, M.; et al. World Allergy Organization-McMaster University Guidelines for allergic disease prevention (GLAD-P): Probiotics. World Allergy Organ J. 2015, 8, 4. [CrossRef] [PubMed]

74. Carabotti, M.; Maselli, M.A.; Severi, C. The gut-brain axis: Interactions between enteric microbiota, central and enteric nervous systems. Ann. Gastroenterol. 2015, 28, 203-209. [PubMed]

75. Mayer, E.A.; Savidge, T.; Shulman, R.J. Brain Gut Microbiome Interactions and Functional Bowel Disorders. Gastroenterology 2014, 146, 1500-1512. [CrossRef] [PubMed]

76. Cryan, J.F.; Dinan, T.G. Mind-altering microorganisms: The impact of the gut microbiota on brain and behavior. Nat. Rev. Neurosci. 2012, 13, 701-712. [CrossRef] [PubMed]

77. Mayer, E.A.; Padua, D.; Tillisch, K. Altered brain-gut axis in autism: Comorbidity or causative mechanisms? Bioessays 2014, 36, 933-939. [CrossRef] [PubMed]

78. Roman, P.; Rueda-Ruzafa, L.; Cardona, D.; Cortes-Rodriguez, A. Gut brain axis in the executive function of autism spectrum disorder. Behav. Pharmacol. 2018, 29, 654-663. [CrossRef] [PubMed]

79. Park, A.J.; Collins, J.; Blennerhassett, P.A.; Ghia, J.E.; Verdu, E.F.; Bercik, P.; Collins, S.M. Altered colonic function and microbiota profile in a mouse model of chronic depression. Neurogastroenterol. Motil. 2013, 25. [CrossRef] [PubMed] 
80. Foster, J.A.; McVey Neufeld, K.A. Gut-brain axis: How the microbiome influences anxiety and depression. Trends Neurosci. 2013, 36, 305-312. [CrossRef] [PubMed]

81. Crumeyrolle-Arias, M.; Jaglin, M.; Bruneau, A.; Vancassel, S.; Cardona, A.; Daugé, V.; Naudon, L.; Rabot, S. Absence of the gut microbiota enhances anxiety-like behavior and neuroendocrine response to acute stress in rats. Psychoneuroendocrinology 2014, 42, 207-217. [CrossRef] [PubMed]

82. Amaral, F.A.; Sachs, D.; Costa, V.V.; Fagundes, C.T.; Cisalpino, D.; Cunha, T.M.; Ferreira, S.H.; Cunha, F.Q.; Silva, T.A.; Nicoli, J.R.; et al. Commensal microbiota is fundamental for the development of inflammatory pain. Proc. Natl. Acad. Sci. USA 2008, 105, 2193-2197. [CrossRef] [PubMed]

83. Mayer, E.A.; Tillisch, K.; Gupta, A. Gut/brain axis and microbiota. J. Clin. Investig. 2015, 125, 926-938. [CrossRef] [PubMed]

84. Arentsen, T.; Qian, Y.; Gkotzis, S.; Femenia, T.; Wang, T.; Udekwu, K.; Forssberg, H.; Heijtz, R.D. The bacterial peptidoglycan-sensing molecule Pglyrp2 modulates brain development and behavior. Mol. Psychiatry 2017, 22, 257-266. [CrossRef] [PubMed]

85. Heijtz, R.D.; Wang, S.; Anuar, F.; Quian, F.; Bjorkholm, B.; Samuelsson, A.; Hibberd, M.; Forssberg, H.; Petterson, S. Normal gut microbiota modulates brain development and behavior. Proc. Natl. Acad. Sci. USA 2011, 108, 3047-3052. [CrossRef] [PubMed]

86. De Palma, G.; Blennerhassett, P.; Lu, J.; Deng, Y.; Park, A.J.; Green, W.; Denou, E.; Silva, M.A.; Santacruz, A.; Sanz, Y.; et al. Microbiota and host determinants of behavioural phenotype in maternally separated mice. Nat. Commun. 2015, 6, 7735. [CrossRef] [PubMed]

87. Varghese, A.K.; Verdú, E.F.; Bercik, P.; Khan, W.I.; Blennerhassett, P.A.; Szechtman, H.; Collins, S.M. Antidepressants attenuate increased susceptibility to colitis in a murine model of depression. Gastroenterology 2006, 130, 1743-1753. [CrossRef] [PubMed]

88. Lippmann, M.; Bress, A.; Nemeroff, C.B.; Plotsky, P.M.; Monteggia, L.M. Long-term behavioural and molecular alterations associated with maternal separation in rats. Eur. J. Neurosci. 2007, 25, 3091-3098. [CrossRef] [PubMed]

89. Gareau, M.G.; Silva, M.A.; Perdue, M.H. Pathophysiological mechanisms of stress-induced intestinal damage. Curr. Mol. Med. 2008, 8, 274-281. [CrossRef] [PubMed]

90. Barreau, F.; Ferrier, L.; Fioramonti, J.; Bueno, L. Neonatal maternal deprivation triggers long term alterations in colonic epithelial barrier and mucosal immunity in rats. Gut 2004, 53, 501-506. [CrossRef] [PubMed]

91. Gareau, M.G.; Jury, J.; Perdue, M.H. Neonatal maternal separation of rat pups results in abnormal cholinergic regulation of epithelial permeability. Am. J. Physiol. Gastrointest. Liver Physiol. 2007, 293, G198-G203. [CrossRef] [PubMed]

92. Oines, E.; Murison, R.; Mrdalj, J.; Gronli, J.; Milde, A.M. Neonatal maternal separation in male rats increases intestinal permeability and affects behavior after chronic social stress. Physiol. Behav. 2012, 105, 1058-1066. [CrossRef] [PubMed]

93. Hyland, N.P.; Julio-Pieper, M.; O’Mahony, S.M.; Bulmer, D.C.; Lee, K.; Quigley, E.M.; Dinan, T.G.; Cryan, J.F. A distinct subset of submucosal mast cells undergoes hyperplasia following neonatal maternal separation: A role in visceral hypersensitivity? Gut 2009, 58, 1029-1030. [CrossRef] [PubMed]

94. O'Mahony, S.M.; Marchesi, J.R.; Scully, P.; Codling, C.; Ceolho, A.M.; Quigley, E.M.; Cryan, J.F.; Dinan, T.G. Early life stress alters behavior, immunity, and microbiota in rats: Implications for irritable bowel syndrome and psychiatric illnesses. Biol. Psychiatry 2009, 65, 263-267. [CrossRef] [PubMed]

95. Jasarevic, E.; Rodgers, A.B.; Bale, T.L. A novel role for maternal stress and microbial transmission in early life programming and neurodevelopment. Neurobiol. Stress 2015, 1, 81-88. [CrossRef] [PubMed]

96. Desbonnet, L.; Garrett, L.; Clarke, G.; Kiely, B.; Cryan, J.F.; Dinan, T.G. Effects of the probiotic Bifidobacterium infantis in the maternal separation model of depression. Neuroscience 2010, 170, 1179-1188. [CrossRef] [PubMed]

97. Eutamene, H.; Bueno, L. Role of probiotics in correcting abnormalities of colonic flora induced by stress. Gut 2007, 56, 1495-1497. [CrossRef] [PubMed]

98. Gareau, M.G.; Jury, J.; Macqueen, G.; Sherman, P.M.; Perdue, M.H. Probiotic treatment of rat pups normalises corticosterone release and ameliorates colonic dysfunction induced by maternal separation. Gut 2007, 56, 1522-1528. [CrossRef] [PubMed] 
99. Sudo, N.; Chida, Y.; Aiba, Y.; Sonoda, J.; Oyama, N.; Yu, X.N.; Kubo, C.; Koga, Y. Postnatal microbial colonization programs the hypothalamic-pituitary-adrenal system for stress response in mice. J. Physiol. 2004, 558, 263-275. [CrossRef] [PubMed]

100. Neufeld, K.M.; Kang, N.; Bienenstock, J.; Foster, J.A. Reduced anxiety-like behavior and central neurochemical change in germ-free mice. Neurogastroenterol. Motil. 2011, 23, 255-264. [CrossRef] [PubMed]

101. Bravo, J.A.; Forsythe, P.; Chew, M.V.; Escaravage, E.; Savignac, H.M.; Dinan, T.G.; Bienenstock, J.; Cryan, J.F. Ingestion of Lactobacillus strain regulates emotional behavior and central GABA receptor expression in a mouse via the vagus nerve. Proc. Natl. Acad. Sci. USA 2011, 108, 16050-16055. [CrossRef] [PubMed]

102. Arseneault-Bréard, J.; Rondeau, I.; Gilbert, K.; Girard, S.A.; Tompkins, T.A.; Godbout, R.; Rousseau, G. Combination of Lactobacillus Helveticus R0052 and Bifidobacterium longum RO175 reduces post-myocardial infarction depression symptoms restores intestinal permeability in a rat model. Br. J. Nutr. 2012, 107, 1793-1799. [CrossRef] [PubMed]

103. Messaoudi, M.; Violle, N.; Bisson, J.; Desor, D.; Javelot, H.; Rougeot, C. Beneficial psychological effects of a probiotic formulation (Lactobacillus helveticus R0052 and Bifidobacterium longum R0175) in healthy human volunteers. Gut Microbes 2011, 2, 256-261. [CrossRef] [PubMed]

104. Huang, R.; Wang, K.; Hu, J. Effect of Probiotics on Depression: A Systematic Review and Meta-Analysis of Randomized Controlled Trials. Nutrients 2016, 8, 483. [CrossRef] [PubMed]

105. McNabney, S.M.; Henagan, T.M. Short Chain Fatty Acids in the Colon and Peripheral Tissues: A focus on Butyrate, Colon Cancer, Obesity and Insulin Resiatance. Nutrients 2017, 9, 1348. [CrossRef] [PubMed]

106. Duca, F.A.; Swartz, T.D.; Sakar, Y.; Covasa, M. Increased oral detection, but decreased intestinal signaling for fats in mice lacking gut microbiota. PLoS ONE 2012, 7, e39748. [CrossRef] [PubMed]

107. Savignac, H.M.; Tramullas, M.; Kiely, B.; Dinan, T.G.; Cryan, J.F. Bifidobacteria modulate cognitive processes in an anxious mouse strain. Behav. Brain Res. 2015, 287, 59-72. [CrossRef] [PubMed]

108. Distrutti, E.; O’Reilly, J.A.; McDonald, C.; Cipriani, S.; Renga, B.; Lynch, M.A.; Fiorucci, S. Modulation of intestinal microbiota by the probiotic VSL\#3 resets brain gene expression ameliorates the age-related deficit in LTP. PLoS ONE 2014, 9, e106503.

109. Di Mauro, A.; Neu, J.; Riezzo, G.; Raimondi, F.; Martinelli, D.; Francavilla, R.; Indrio, F. Gastrointestinal function development and microbiota. Ital. J. Pediatr. 2013, 39, 15. [CrossRef] [PubMed]

110. Sung, V. Infantile colic. Aust. Prescr. 2018, 41, 105-110. [PubMed]

111. Zeevenhooven, J.; Koppen, I.J.; Benninga, M.A. The New Rome IV Criteria for Functional Gastrointestinal Disorders in Infants and Toddlers. Pediatr. Gastroenterol. Hepatol. Nutr. 2017, 20, 1-13. [CrossRef] [PubMed]

112. Shamir, R.; St James-Roberts, I.; Di Lorenzo, C.; Burns, A.J.; Thapar, N.; Indrio, F.; Riezzo, G.; Raimondi, F.; Di Mauro, A.; Francavilla, R.; et al. Infant crying, colic, and gastrointestinal discomfort in early childhood: A review of the evidence and most plausible mechanisms. J. Pediatr. Gastroenterol. Nutr. 2013, 57 (Suppl. 1), S1-S45. [CrossRef] [PubMed]

113. Dryl, R.; Szajewska, H. Probiotics for management of infantile colic: A systematic review of randomized controlled trials. Arch. Med. Sci. 2018, 14, 1137-1143. [CrossRef] [PubMed]

114. Partty, A.; Kalliomaki, M.; Salminen, S.; Isolauri, E. Infant distress and development of functional gastrointestinal disorders in childhood: Is there a connection? JAMA Pediatr. 2013, 167, 977-978. [CrossRef] [PubMed]

115. Baldassarre, M.E.; Di Mauro, A.; Mastromarino, P.; Fanelli, M.; Martinelli, D.; Urbano, F.; Capobianco, D.; Laforgia, N. Administration of a Multi-Strain Probiotic Product to Women in the Perinatal Period Differentially Affects the Breast Milk Cytokine Profile and May Have Beneficial Effects on Neonatal Gastrointestinal Function Symptoms. A Randomized Clinical Trial. Nutrients 2016, 8, 677. [CrossRef] [PubMed]

116. Baldassarre, M.E.; Di Mauro, A.; Tafuri, S.; Rizzo, V.; Gallone, M.S.; Mastromarino, P.; Capobianco, D.; Laghi, L.; Zhu, C.; Capozza, M.; et al. Effectiveness and Safety of a Probiotic-Mixture for the Treatment of Infantile Colic: A Double-Blind, Randomized, Placebo-Controlled Clinical Trial with Fecal Real-Time PCR and NMR-Based Metabolomics Analysis. Nutrients 2018, 10, 195. [CrossRef] [PubMed]

117. Gutiérrez-Castrellón, P.; Indrio, F.; Bolio-Galvis, A.; Jiménez-Gutiérrez, C.; Jimenez-Escobar, I.; López-Velázquez, G. Efficacy of Lactobacillus reuteri DSM17938 for infantile colic: Systematic review with network meta-analysis. Medicine 2017, 96, e9375. [CrossRef] [PubMed] 
118. Indrio, F.; Di Mauro, A.; Riezzo, G.; Civardi, E.; Intini, C.; Corvaglia, L.; Ballardini, E.; Bisceglia, M.; Cinquetti, M.; Brazzoduro, E.; et al. Prophylactic use of a probiotic in the prevention of colic, regurgitation, and functional constipation: A randomized clinical trial. JAMA Pediatr. 2014, 168, 228-233. [CrossRef] [PubMed]

119. Sung, V.; D'Amico, F.; Cabana, M.D.; Chau, K.; Koren, G.; Savino, F.; Szajewska, H.; Deshpande, G.; Dupont, C.; Indrio, F.; et al. Lactobacillus reuteri to Treat Infant Colic: A Meta-analysis. Pediatrics 2018, 141, e20171811. [CrossRef] [PubMed]

120. Boyle, R.J.; Robins-Browne, R.M.; Tang, M.L. Probiotic use in clinical practice: What are the risks? Am. J. Clin. Nutr. 2006, 83, 1256-1264. [CrossRef] [PubMed]

121. Besselink, M.G.; van Santvoort, H.C.; Buskens, E.; Boermeester, M.A.; van Goor, H.; Timmerman, H.M.; Nieuwenhuijs, V.B.; Bollen, T.L.; van Ramshorst, B.; Witteman, B.J.; et al. Probiotic prophylaxis in predicted severe acute pancreatitis: A randomised, double-blind, placebo-controlled trial. Lancet 2008, 371, 651-659. [CrossRef]

122. Allen, S.J.; Jordan, S.; Storey, M.; Thornton, C.A.; Gravenor, M.; Garaiova, I.; Plummer, S.F.; Wang, D.; Morgan, G. Dietary supplementation with lactobacilli and bifidobacteria is well tolerated and not associated with adverse events during late pregnancy and early infancy. J. Nutr. 2010, 140, 483-488. [CrossRef] [PubMed]

123. Luoto, R.; Laitinen, K.; Nermes, M.; Isolauri, E. Impact of maternal probiotic-supplemented dietary counselling on pregnancy outcome and prenatal and postnatal growth: A double-blind, placebo-controlled study. Br. J. Nutr. 2010, 103, 1792-1799. [CrossRef] [PubMed]

124. Kuitunen, M.; Kukkonen, K.; Savilahti, E. Pro- and prebiotic supplementation induces a transient reduction in hemoglobin concentration in infants. J. Pediatr. Gastroenterol. Nutr. 2009, 49, 626-630. [CrossRef] [PubMed]

125. Hooper, L.V.; Littman, D.R.; Macpherson, A.J. Interactions between the microbiota and the immune system. Science 2012, 336, 1268-1273. [CrossRef] [PubMed]

126. Rudensky, A.Y.; Chervonsky, A.V. A narrow circle of mutual friends. Immunity 2011, 27, 697-699. [CrossRef] [PubMed]

127. Baldassarre, M.E. Probiotic Genera/Species Identification Is Insufficient for Evidence-Based Medicine. Am. J. Gastroenterol. 2018, 113, 1561. [CrossRef] [PubMed]

128. Kolacek, S.; Hojsak, I.; Canani, R.B.; Guarino, A.; Indrio, F.; Pot, B.; Shamir, R.; Szajewska, H.; Vandenplas, Y.; van Goudoever, J.; et al. Commercial probiotic products: A call for improved quality control. A Position Paper by the ESPGHAN Working Group for Probiotics and Prebiotics. J. Pediatr. Gastroenterol. Nutr. 2017, 65, 117-124. [CrossRef] [PubMed]

(C) 2018 by the authors. Licensee MDPI, Basel, Switzerland. This article is an open access article distributed under the terms and conditions of the Creative Commons Attribution (CC BY) license (http://creativecommons.org/licenses/by/4.0/). 